\title{
Sjögren's syndrome, dysimmunoglobulinaemia and malignant disease
}

\author{
Peter Thomas* \\ M.B., B.S.
}

Brompton Hospital and Institute for Diseases of the Chest, London S.W.3

\begin{abstract}
Summary
The occurrence of carcinoma in situ in the stomach and dysimmunoglobulinaemia in a patient who had Sjögren's syndrome is described. This is believed to be the first report of such a case to be found in the literature.
\end{abstract}

Although carcinoma has occasionally been described, in this syndrome its occurrence is probably coincidental and not part of the disease process. There is a greater incidence of lymphoid tumours in Sjögren's syndrome than in the general population. Corticosteroid therapy favourably influenced the immunoglobulin abnormalities and some of the clinical manifestations of the disease.

A brief review of the literature concerning Sjögren's syndrome, auto-immunity and malignant disease is included.

\section{Introduction}

In 1933 Henrik Sjögren, a Swedish ophthalmologist, described a syndrome with the characteristic triad of keratoconjunctivitis sicca, xerostomia and recurrent swelling of the parotid glands (Sjögren, 1933).

Previously, in 1892, von Mickulicz had reviewed the literature showing that enlargement of the parotid, submandibular and lacrimal glands was part of a benign disease process and could be differentiated from similar swellings occurring in tuberculosis, leukaemia and malignant lymphomas and which are now known to occur with sarcoidosis, connective tissue disorders and auto-immune reactions (Mickulicz, 1892). In 1945 Riva suggested that the term Mickulicz's syndrome should be reserved for cases with swelling of the parotid and lacrimal glands without major secretory disturbances, to differentiate it from Sjögren's syndrome in which secretory disturbances were present. In 1953 Morgan \& Castleman showed that the pathological changes in the parotid glands were identical in both conditions. These changes included replacement of acinar parenchyma by lymphocytes, intraductal prolifera-

\footnotetext{
* Present address: Department of Gastroenterology, University Hospital of Wales, Heath Park, Cardiff.
}

tion of epithelial and myoepithelial cells and the formation of epimyoepithelial islands (Morgan \& Castleman, 1953). Sjögren's syndrome is now known to be part of a wide spectrum of disease which includes rheumatoid arthritis (Bloch \& Bunim, 1963; Denko \& Bergenstal, 1960), Raynaud's phenomenon (Bloch \& Bunim, 1963; Stoltze et al., 1960), pulmonary fibrosis (Stoltze et al., 1960; Bucher \& Reid, 1959; Bloch et al., 1965), purpura associated with hyperglobulinaemia (Talal, 1966), systemic lupus erythematosus (Heaton, 1959), scleroderma (Bloch et al., 1965), pancreatitis and chronic hepatobiliary defects (Zawadzki \& Edwards, 1970), neurological disease (Denko \& Old, 1969; Attwood \& Poser, 1961), and malignant lymphomas (Pinkus \& Dekker, 1970; Talal \& Bunim, 1964; Talal, Sokoloff \& Barth, 1967; Bunim \& Buchanan, 1964; Anderson \& Talal, 1971). Other neoplasms are rarely found in association with the syndrome and probably occur by chance as incidental findings. Those that have been described include carcinoma of the parotid gland (Delaney \& Balogh, 1966), mixed parotid tumour (Stoltze et al., 1960), thymoma (Lattes, 1962), carcinoma of the breast and cervical carcinoma (Sage \& Forbes, 1968).

Here is recorded details of a patient with Sjögren's syndrome who developed dysimmunoglobulinaemia, lymphadenopathy, splenomegaly, purpura and carcinoma in situ of the stomach.

\section{Case report}

A 56-year-old woman was admitted to hospital in February 1963 complaining of a cough with mucoid sputum which had been present for 5 months together with intermittent, painful, bilateral swelling in the region of the parotid glands for 4 years. She had been diagnosed as having mumps by her family doctor and over the next few months the swellings gradually subsided. One year later similar swellings occurred but this time they persisted (Fig. 1). Systematic questioning revealed dryness of the mouth and soreness of the eyes. Tears were present on stimulation. For 1 year pain in the knees and elbows had been noted but at no time was there swelling, stiffness 


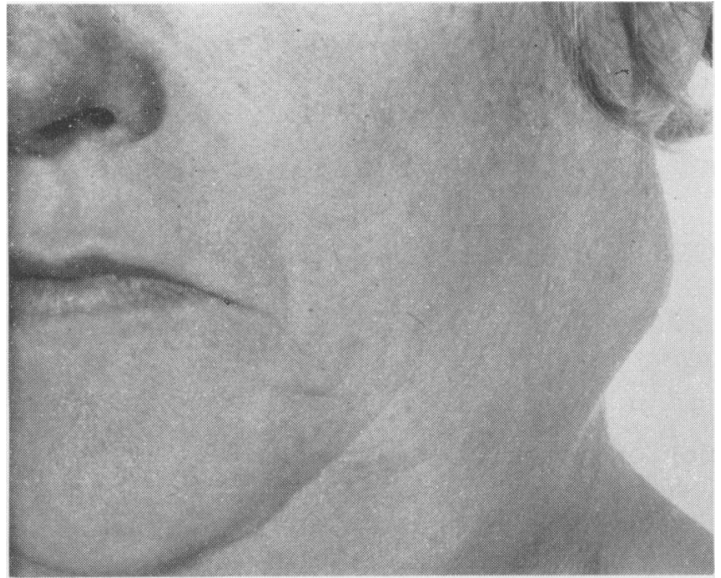

FIG. 1. Parotid enlargement in the patient with Sjögren's syndrome.

or limitation of movement. Her appetite was poor, and she had lost 1 stone in weight over the past few months. She did not suffer from shortness of breath, pain in the chest, peripheral circulatory disturbances, swelling of the ankles, headaches, bowel upsets or skin rashes. The past medical history revealed nothing relevant. She was married with two healthy children. She had smoked ten cigarettes a day for many years. She was taking no medication.

Examination revealed an overweight middle-aged woman. The eyes were slightly inflamed, the lacrimal glands were enlarged and some mucoid exudate was present. Both parotid glands were enlarged and cystic, mobile but not tender. The other salivary glands were not enlarged. Saliva and tears were secreted. Ophthalmological examination showed changes typical of a mild keratoconjunctivitis sicca syndrome. Schirmer's test was positive. All other systems including the musculo-skeletal system were normal.

Investigations. $\mathrm{Hb} 10 \mathrm{~g} / 100 \mathrm{ml}$. MCHC $31 \%$. WBC $4500,71 \%$ neutrophils, $19 \%$ lymphocytes and $10 \%$ monocytes. ESR $17 \mathrm{~mm} / \mathrm{hr}$, Westergren. The following investigations revealed no abnormality: urea and electrolytes, liver function tests, serum proteins, albumin, globulin, electrophoretic strip, sputum, lung function tests and radiology of the chest and joints. The latex fixation test was positive, the Rose-Waaler test was negative with a differential agglutination titre of 1 in 2 . Antibodies to lacrimal and salivary glands were not detected. Biopsy of the parotid gland showed gland tissue had been largely replaced by lymphocytic infiltration. A few epithelialized glandular spaces persisted. The appearance was consistent with that of a benign lymphoepithelioma compatible with Sjögren's syndrome
(Fig. 2). A lymph node taken from the left supraclavicular fossa was histologically normal and there was no evidence of lymphoma. Biopsy of a conjunctival follicle showed a non-specific follicular lymphoid reaction.

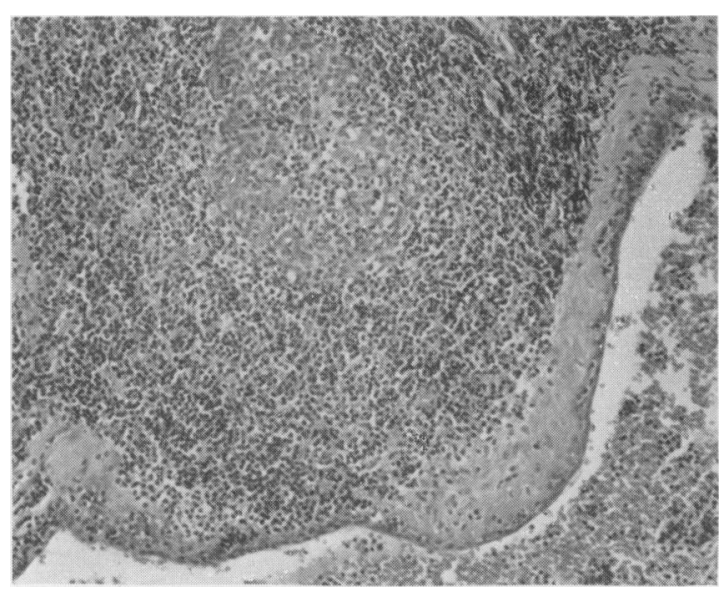

FIG. 2. Section of parotid gland removed at biopsy, showing epimyoepithelial islands and hyalinization surrounded by lymphocytic infiltration.

\section{Subsequent course of the disease}

Eighteen months later serum proteins were: totakb $7 \cdot 2 \mathrm{~g} / 100 \mathrm{ml}$, albumin $4 \cdot 1 \mathrm{~g} / 100 \mathrm{ml}$, globulin $3 \cdot 1 ?$ $\mathrm{g} / 100 \mathrm{ml}$, IgG $1300 \mathrm{mg} / 100 \mathrm{ml}$, IgA $150 \mathrm{mg} / 100 \mathrm{ml}$, $\operatorname{IgM} 240 \mathrm{mg} / 100 \mathrm{ml}$. The latter was a diffuse solitary band.

Over the next 2 years she was noted to have an urticarial and erythematous rash on the extensor aspect of the lower limbs. Her hands were blue and cold and she had Raynaud's syndrome. Relevant investigations performed included a negative test for cryoglobulins, cold agglutinins, antinuclear factors, LE cells and salivary duct antibody. The Wasserman reaction was negative. Kveim test was negative. The Mantoux test was positive 1 in 10,000 . The radiograph and lung function studies, including transfer factor, were normal. The haemoglobin was 10.5 $\mathrm{g} / 100 \mathrm{ml}$. The blood film showed a mild degree of iron deficiency and she was commenced on oral iron therapy. In 1969 the haemoglobin was $12.9 \mathrm{~g} / 100 \mathrm{ml}$.

Eight years following her first admission to hospital she was re-admitted with a severe recurrence of the painful, purpuric, maculopapular rash on her legs. The lesions occurred in crops, lasted for $24 \mathrm{hr}$ and gradually subsided over 2-3 days. There had not been any change regarding her eyes, cough, Raynaud's syndrome or parotid swelling.

Examination revealed an obese woman with a pyrexia of $38^{\circ} \mathrm{C}$. There was pitting ankle oedema associated with a fading rash on the extensor aspects 
of the lower limbs. The thyroid gland was not enlarged. The parotid glands were swollen as before. Rubbery hard lymph nodes, measuring $0.5-1 \mathrm{~cm}$ were palpable in the anterior and posterior triangles of the neck, axilla and inguinal regions. The spleen was palpable $2 \mathrm{~cm}$ below the costal margin. The liver was not enlarged. Other systems were clinically normal.

Investigations. $\mathrm{Hb} 10.5 \mathrm{~g} / 100 \mathrm{ml}$, white cells were normal, ESR $47 \mathrm{~mm} / \mathrm{hr}$, Westergren, platelets 200,000 . Hess's test was negative. The blood film showed occasional hypochromic red blood cells. Bone marrow examination was normal. There were adequate iron stores. Prothrombin time, bleeding time, clotting time and clotting factors were normal. Total serum protein was $4.8 \mathrm{~g} / 100 \mathrm{ml}$, albumin $2 \cdot 7 \mathrm{~g} / 100 \mathrm{ml}$, globulin $2 \cdot 1 \mathrm{~g} / 100 \mathrm{ml}$. Alpha 1 , alpha 2 and alpha 3 globulins were elevated. IgG $187 \mathrm{mg} /$ $100 \mathrm{ml}, \operatorname{IgA} 25 \mathrm{mg} / 100 \mathrm{ml}$, IgM $250 \mathrm{mg} / 100 \mathrm{ml}$. The haemolytic titre count was normal. Iso haemoglutinins were A rhesus-positive with an anti-B titre of 1 in 4. Latex fixation test was positive. Mancini complement was normal. Antinuclear factor was negative. Rose-Waaler test was negative, with a differential agglutination titre of 1 in 2. Other organ specific antibodies were not detected. The Wasserman reaction was positive as were the VDRL and Reiter protein complement fixation tests. The Treponema pallidum immobilization test and Treponema fluorescent antibody tests were negative. Mantoux and Candida skin tests were positive. Urinary protein was $0.36 \mathrm{~g} / 24 \mathrm{hr}$. No Bence-Jones protein was found. The blood urea and the creatinine clearance tests were normal. Radiographs of the chest and skeletal system were normal. The ECG was normal. A lymph node taken from the left axilla was histologically normal. There was no evidence of lymphoma.

While in hospital she developed pain in the upper abdomen and she vomited bright red blood and passed blood in the motions. A barium meal showed a constant filling defect in the pyloric antrum and a constant irregularity of the greater and lesser curves of the pyloric antrum together with the lower half of the body of the stomach. The appearance was consistent with the presence of a neoplasm in the pyloric antrum. Gastroscopy confirmed the findings and a laparotomy was performed at which time an adenoma of the pyloric antrum and a lymph node from the stomach bed were excised. The latter showed reactive changes with sinus cell hyperplasia and fibrosis. There was no evidence of malignancy. The piece of stomach showed a raised area measuring $1.5 \times 1.2 \mathrm{~cm}$. There was severe atrophic gastritis with intestinal metaplasia bearing a sessile adenomatous polyp. This showed focal in situ carcinoma and evidence of extremely early invasion (Fig. 3). Excision seemed complete.

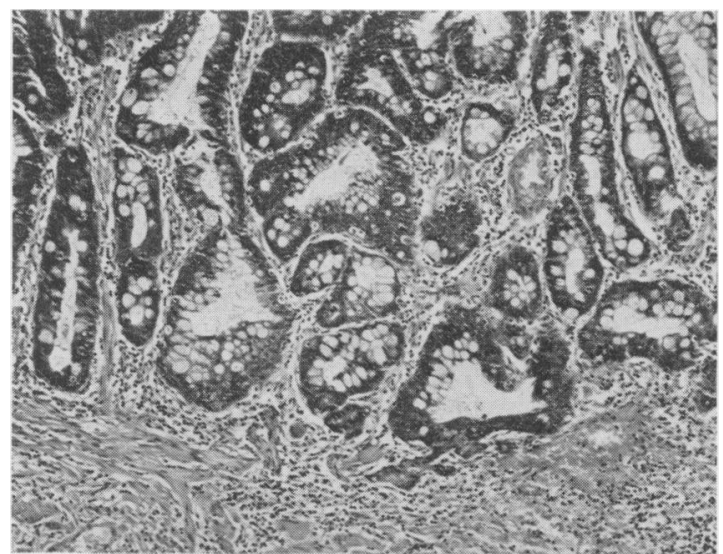

FIG. 3. Section of stomach wall showing focal early invasive carcinoma in situ.

During 5 months of observation the rash recurred on many occasions and the oedema, lymphadenopathy and splenomegaly persisted. Prednisone $10 \mathrm{mg}$ daily was given and within 1 month the rash and peripheral oedema had cleared and the spleen had become impalpable. Within 4 months the generalized lymphadenopathy had disappeared and the size of the parotid swellings had decreased. Six months after starting treatment the immunoglobulins were as follows: IgG $625 \mathrm{mg} / 100 \mathrm{ml}$, IgA $62 \mathrm{mg} / 100 \mathrm{ml}$, IgM $140 \mathrm{mg} / 100 \mathrm{ml}$. The patient remains extremely well whilst continuing prednisone.

\section{Discussion}

Sjögren's syndrome is a chronic disorder predominantly affecting middle-aged or elderly females, in which there is chronic inflammation of the lacrimal and salivary glands resulting in atrophy of gland acini and diminution of secretory capacity. The diagnosis of Sjögren's syndrome requires two of the following three components: xerostomia, keratoconjunctivitis sicca and rheumatoid arthritis. Lacrimal or salivary gland involvement is variable (Bloch et al., 1965).

Malignant lymphomas are known to be commoner in Sjögren's syndrome than in the general population (Pinkus \& Dekker, 1970; Talal \& Bunim, 1964; Talal et al., 1967; Bunim et al., 1964; Anderson \& Talal, 1971). Previous reports showed a predominance of reticulum-cell sarcoma but other lymphomas such as Hodgkin's disease, giant follicular lymphoma and pseudolymphoma have been described.

In the majority of patients with Sjögren's syndrome lacrimal and salivary glands are infiltrated with lymphoid cells with progressive destruction of acini and proliferation of ductal epithelial cells eventually forming the epimyoepithelial islands. These benign 
local lympho-epithelial lesions give rise to the dry mouth and dry eyes typical of the syndrome. In some patients the lymphoproliferation extends beyond the salivary and lacrimal glands and the term 'pseudolymphoma' has been used to describe the lesions which show tumour cell aggregates but none of the other criteria necessary for malignancy (Talal et al., 1967; Anderson \& Talal, 1971). In other patients, extraglandular lymphoid proliferation becomes frankly malignant giving rise to reticulum cell sarcoma and Hodgkin's disease. Malignant lymphomas may or may not be preceded by benign infiltrates of the lacrimal or salivary glands and may occur several years after the diagnosis of Sjögren's syndrome has been made. There have been several reports of Waldenstrom's macroglobulinaemia complicating Sjögren's syndrome where there was excessive production of $\mathrm{IgM}$ in the presence os extraglandular lymphoproliferation (Talal et al., 1967; Anderson \& Talal, 1971).

It has been shown that benign hyperplasia of the reticulo-endothelial system predisposes to the development of malignant lymphoma (Lea, 1964). Also acquired or congenitial immune-deficiency states may be complicated by malignant lymphomas such as reticulum-cell sarcoma (Doaks et al., 1968) or lymphosarcoma (Penn et al., 1969). When malignant lymphoma complicates Sjögren's syndrome several characteristic changes occur. There may be enlargement of the lymph nodes and spleen. Several cases have been reported where patients with Sjögren's syndrome died many years after the start of the disease after developing lymphadenopathy and splenomegaly. At necropsy, histology showed that the patient had developed a malignant lymphoma, usually a reticulum-cell sarcoma (Talal et al., 1967; Bunim et al., 1964; Anderson \& Talal, 1971).

In Sjögren's syndrome there is an increased synthesis of IgG, IgM and $\operatorname{IgA}$ by the lymphocytic cells infiltrating the lacrimal and salivary glands (Talal, Asofsky \& Lightbody, 1970). The highest elevation in the majority of patients with benign Sjögren's syndrome occurs in the IgM fraction of the immunoglobulins and those patients who eventually develop malignant lymphomas have a disproportionately elevated IgM (Talal et al., 1967). A fall in the level of the IgG or IgM may precede the development of a malignant lymphoma (Pinkus \& Dekker, 1970; Talal \& Bunim, 1964; Talal et al., 1967; Bunim et al., 1964; Anderson \& Talal, 1971). The majority of patients with Sjögren's syndrome have a positive Rose-Waaler test for rheumatoid arthritis and almost all have a positive bentonite or latex-flocculation test (Bunim, 1961; Feltkamp \& Van Rossum, 1968). The patients with negative Rose-Waaler tests are more likely to develop malignant lymphomas at a later date (Bloch et al.,
1965; Talal \& Bunim, 1964; Talal et al., 1967; Anderson \& Talal, 1971). Other factors in Sjögren's syndrome which are known to predispose to the development of malignant lymphoma include the presence of vasculitis, Raynaud's syndrome (Pinkus \& Dekker, 1970; Lea, 1964), a raised alpha 3 globulin (personal communication-Professor J. Hobbs), a biological false-positive test for syphilis or a preexisting cryoglobulinaemia (Talal et al., 1967; Maleville et al., 1967).

Over the period of 8 years the patient described in this review developed lymphadenopathy, splenomegaly, vasculitis, Raynaud's syndrome, a fall in the serum $\operatorname{IgG}$ and $\operatorname{IgA}$, a disproportionate rise in the serum IgM, a raised alpha 3 globulin and a biological false-positive test for syphilis. The RoseWaaler test was negative and cryoglobulins were never detected. Three lymph node biopsies revealed no evidence of malignant lymphoma. However, carinoma of the stomach complicated the disease in this patient.

Other malignant lymphoproliferative disorders have been described in association with Sjögren's syndrome. These include thymoma (Pinkus \& Dekker, 1970; Lattes, 1962) and lymphosarcoma (Dameshek, 1965; Thorpe, 1969), and also three cases have more recently been described in which parotid masses occurred following excision-distant metastases appeared which histologically were described as poorly differentiated carcinoma or malignant lympho-epithelial lesions (Gravanis \& Giansanti, 1970). Malignant lesions other than lymphomas are rare in Sjögren's syndrome and probably are not part of the disease process. As mentioned in the introduction these include carcinoma of the parotid gland, mixed parotid tumour, carcinoma of the breast and cervical carcinoma. This paper describes the first case of carcinoma of the stomach to be found complicating Sjögren's syndrome and like the above carcinomas is probably only a chance finding. A group of workers have recently described patients with Sjögren's syndrome in which post-cricoid pharyngeal webs were present in the absence of iron-deficiency anaemia. They did not find any patients with oesophageal tumours but the follow-up period may reveal yet another malignant complication of Sjögren's syndrome (Doig et al., 1971).

Sjögren's syndrome is one of a group of diseases associated with auto-immune antibodies. There are many types, organ and non-organ specific, or complement-fixing and precipitating antibodies. Hypergammaglobulinaemia is found in approximately $50 \%$ of cases (Bunim, 1964). Antibodies against salivary duct epithelium are present in the majority of cases of Sjögren's syndrome. Figures have varied between $53 \%$ (Feltkamp \& Van Rossum, 
1968) and $72 \%$ (Bertram \& Holberg, 1964). These auto-antibodies are also present in other diseases, e.g. rheumatoid arthritis $22 \%$, systemic lupus erythematosus $18 \%$ and myasthenia gravis $11 \%$. They are rare in pernicious anaemia and Hashimoto's thyroiditis (Feltkamp \& Van Rossum, 1968). MacSween et al. found salivary duct antibodies in more patients with Sjögren's syndrome and rheumatoid arthritis than in patients with Sjögren's syndrome and the sicca syndrome alone (MacSween et al., 1967). Feltkamp \& Van Rossum (1968) found no difference between the groups, neither did they find antibodies in their matched control subjects. They noted antibodies to smooth muscle in $19 \%$ of cases but did not find an increase of antibodies to skeletal muscle, gastric parietal cells, thyroid cells or mitochondria. Doniach et al. demonstrated antimitochondrial antibodies in the undiluted serum of nearly $100 \%$ of patients with primary biliary cirrhosis, $20 \%$ of patients with auto-immune hepatitis, systemic lupus erythematosus and rheumatoid arthritis. They found no increased incidence in patients with Sjögren's syndrome (Doniach et al., 1966). Anderson et al. found antibodies to gastric parietal cells in $24 \%$ of patients with Sjögren's syndrome and in $10 \%$ of their control subjects (Anderson et al., 1965).

Antinuclear factor is present in $77 \%$ of cases of Sjögren's syndrome (Feltkamp \& Van Rossum, 1968). Rheumatoid factor is present in $50 \%$ of cases using the Rose-Waaler test and in almost $100 \%$ of cases using the latex or bentonite-flocculation test (Feltkamp \& Van Rossum, 1968). The latter depends on a reaction between a test serum and rabbit gammaglobulin and the former on a reaction between test serum and human $\mathrm{F}_{2}$ gammaglobulin; they therefore do not invariably correlate.

Since auto-antibodies are immunoglobulins it is to be expected that immunoglobulins are elevated in the majority of patients with Sjögren's syndrome. This has been substantiated by many reports, the most recent by Gumpel \& Hobbs (1970). They demonstrated considerable elevations of IgG, IgM and $\operatorname{IgA}$ in their fifty patients with Sjogren's syndrome. Simultaneous elevation of three immunoglobulins was found in $14 \%$ of cases and of two immunoglobulins in $32 \%$. IgM was elevated in more of the patients than either the IgG or IgA. The latter was found to be elevated with the least frequency. There was little difference between immunoglobulin levels in patients with a sicca syndrome alone or in the group with the sicca syndrome and rheumatoid arthritis. Patients with an elevated IgM have a longer period of disease with an increased risk of developing a malignant lymphoma or Waldenstrom's macroglobulinaemia (Talal et al., 1967; Anderson \& Talal, 1971; Gumpel \& Hobbs, 1970).
Researchers have found that when a malignant lymphoma develops in a patient with Sjögren's syndrome the serum levels of IgM and rheumatoid factor may fall. In others the serum gammaglobulin has been shown to decrease with a concomitant appearance of malignancy (Talal \& Bunim, 1964; Anderson \& Talal, 1971). In the patient described in this article the serum gammaglobulin fell from $3 \cdot 1$ to $2 \cdot 1 \mathrm{~g} / 100 \mathrm{ml}$, the latex test for rheumatoid arthritis remained positive, the IgM level remained elevated but the IgG and IgA levels diminished to levels below the mean found in the normal population.

In benign Sjögren's syndrome it is evident that there is marked immunological hyperactivity as shown by lymphocytic infiltration of the salivary and lacrimal glands, hypergammaglobulinaemia, auto-antibody formation and high levels of immunoglobulins. The reason why the immunological system should suddenly show a decreased activity and that this decreased activity should be associated with malignant lymphoma is not understood. Recently, Anderson \& Talal reviewed the current theories concerning the subject (Anderson \& Talal, 1971). Perhaps the most plausible explanation at the current time is that the immunological system becomes either exhausted or that it is damaged by an unknown agent with resulting impairment of immuno-surveillance and the development of malignant lymphocytic tumours. Lymphocytic malignancy is significantly increased in primary hypogammaglobulinaemia and malignant lymphoma and carcinoma are increased in chronic immuno-suppression as occurs in patients treated with azathioprine following renal transplants (Talal et al., 1970; Bunim, 1961).

Auto-allergic phenomena can be suppressed using corticosteroids (Soothill, 1967). The patient described in this article responded to prednisone therapy. The clinical manifestations of the disease improved, the serum IgG rose to within normal limits and the abnormally elevated IgM diminished to within normal limits.

This paper describes a patient with Sjögren's syndrome who developed many of the stigmata which are known to precede the development of malignant lymphoma. However, there was no such occurrence in this case. A carcinoma of the stomach complicated the disease process and this is believed to be the first time that this has been recorded in Sjögren's syndrome. The response of the patient to corticosteroids and the response of the serum immunoglobulins was also noted.

\section{Acknowledgments}

My thanks to Dr K. M. Citron for allowing me to report on his patient and for his valuable aid in the writing of this article; Dr W. Hinson for his advice on the histology; Professor B. Jones for the ophthalmological opinions; Professor Lessof for advising on the endocrinology; Dr Battley 
for his advice on the dermatological problem; Mr N. Tanner for his surgical opinion and Professor J. Hobbs for performing some of the estimations on the immunoglobulins and his advice in the interpretations of these results.

\section{References}

Anderson, J.R., Beck, J.S., Bloch, K., Buchanan, W.W. \& Bunim, J.J. (1965) Auto-immunity in Sjögren's syndrome. Auto-immunity Symposium $V$ Congress. Blackwell Scientific Publications, Oxford.

ANDERSON, L.G. \& TAlal, N. (1171) The spectrum of benign to malignant lympho-proliferation in Sjögren's syndrome. Clinical and Experimental Immunology, 9, 199.

Attwood, W. \& Poser, C.M. (1961) Neurologic complications of Sjögren's syndrome. Neurology, 11, 1034.

Bertram, U. \& Holberg, P. (1964) A specific antibody against the epithelium of salivary ducts in serum from patients with Sjögren's syndrome. Acta allergologica, 19, 458.

Bloch, K.J., Buchanan, W.W., Wohl, M.J. \& Bunim, J.J. (1965) Sjogren's syndrome-A clinical, pathological and serological study of s!xty-two cases. Medicine, 44, 187.

Bloch, K.J. \& Bunim, J.J. (1963) Sjögren's syndrome and it relation to connective tissue disease. Journal of Chronic Diseases, 16, 915.

BUCHER, U.G. \& ReID, L. (1959) Sjögren's syndromeReport of a fatal case with pulmonary and renal lesions. British Journal of Diseases of the Chest, 53, 237.

Bunim, J.J. (1961) A broader spectrum of Sjögren's syndrome and its pathogenetic implications. Annals of the Rheumatic Diseases, 20, 1.

Bunim, J.J., Buchanan, W.W. \& Wertlake, P.T. (1964) Clinical, pathological and serological studies in Sjögren's syndrome. Annals of Internal Medicine, 61, 509

DAMESHEK, W. (1965) Immunological proliferation and its relationship to certain forms of leukaemia and related disorders. Israel Journal of Medical Sciences, 1, 1304.

Delaney, W.E. \& Balogh, K. (1966) Carcinoma of the parotid gland associated with benign lympho-epithelial lesions (Mickulicz's disease) in Sjögren's syndrome. Cancer, 19, 853.

Denko, C.W. \& Bergenstal, D.M. (1960) The sicca syndrome (Sjögren's syndrome)-A study of sixteen cases. Archives of Internal Medicine, 105, 849.

Denko, C.W. \& OLd, J.W. (1969) Myopathy in the sicca syndrome (Sjögren's syndrome). American Journal of Clinical Pathology, 51, 631.

Doaks, P.B., Montgomerie, J.Z., North, J.D. \& Smith, F. (1968) Reticulum cell sarcoma after renal homo-transplantation, azathioprine and prednisone therapy. British Medical Journal, 4, 746.

Doig, J.A., Whalty, K., Dick, W.C., Nuki, G., Williamson, J. \& Buchanan, W.W. (1971) Otolaryngeal aspects of Sjögren's syndrome. British Medical Journal, 4, 460.

Doniach, D., Roitt, I.M., Walker, J.G. \& Sherlock, S. (1966) Tissue antibodies in primary biliary cirrhosis, lupoid hepatitis and other diseases. Clinical and Experimental Immunology, 1, 237.

Feltcamp, T.E. \& Van Rossum, A. (1968) Antibodies to salivary duct cells and other antibodies in patients with Sjögren's syndrome. Clinical and Experimental Immuno$\log y, 3,1$.

Gravanis, M.B. \& Giansanti, J.S. (1970) Malignant histopathologic counterpart of the benign lympho-epithelialesion. Cancer, 26, 133.
GuMPeL, J.M. \& HoBBS, J.R. (1970) Serum immunoglobulins in Sjögren's syndrome. Annals of the Rheumatic Diseases, 29, 681 .

Heaton, J.N. (1959) Sjögren's syndrome and systemic lupus erythematosus. British Medical Journal, 1, 466.

Hobss, J. Personal communication, Westminster Hospital, London.

LATTES, R. (1962) Thymoma and other tumours of the thymus. An analysis of one hundred and seven cases. Cancer, 15, 1224.

LEA, A.J. (1964) An association between the rheumatic diseases and the reticuloses. Annals of the Rheumatic Diseases, 23, 480.

MacSween, R.N.M., Goudie, R.B., Anderson, J.R., Murray, MA., Jasani, M.K., Boyle, J.A., Buchanan, W.W., Willamson, J. \& Mason, D.K. (1967) Observations on the occurrence of antibody to salivary duct epithelium in patients with Sjögrens syndrome, rheumatoid arthritis and other arthritides. Annals of Rheumatic Diseases, 26, 402.

Maleville, J.. Heid, F. Rousselot, P., Bergoend, H., Grosshans, E. \& Araujo, A. (1967) Purpura dysglobulinemique et syndrome de Gougerot-Sjögren. Bulletin de la Societe Francaise de Dermatologie et de Syphiligraphie, 74, 696.

Mickulicz, J. (1892) Uber eine eigneartige symmetrische Erkrankung der Thränen und Mundspeicheldrusen. Beitr. Chir, Festschrift für Billroth, 610.

Morgan, W.D. \& Castleman, B. (1953) A clinicopathologic study of Mickulicz's disease. American Journal of Patho$\log y, 29,471$.

Penn, J., Hammond, W., Brettschneider, L. \& Starzl, T.E. (1969) Malignant lymphomas in transplantatior patients. Transplant Proceedings, 1, 106.

Pinkus, G.S. \& DekKer, A. (1970) Benign lympho-epithelia lesions of parotid glands associated with the reticulunis cell sarcoma. Cancer, 25, 121.

SAGE, R.E., ForbeS, I.J. (1968) A case of multiple autoimmune disease, lymphoid proliferation and hypo-gamma globulinaemia. Blood; Journal of Haematology, 31, 536.

SJöGREN, H. (1933) Zur Kenntinis der Keratoconjunctivitis sicca ( $K$ ratitis filiformis bei Hypofunktion der Tranendrüsen). Acta ophthalmologica, 11, Suppl. 2, 1.

Soothill, J.F. (1967) Quantitative disturbances of plasma proteins in disease. In: Scientific Basis of Medicine, p. 276. Annual Reviews. Athlone Press, London.

Stoltze, C.A., Hanlon, D.G., Pease, G.L. \& Henderson, J.W. (1960) Keratoconjunctivitis sicca and Sjögren's syndrome-Systemic manifestations and haematologic and protein abnormalities. Archives of Internal Medicine 106, 513.

TALAL, N. (1966) Sjögren's syndrome. Bulletin on the Rheumatic Diseases, 16, 404.

Talal, N., Asofsky, R. \& Lightbody, P. (1970) Immunoglobulin synthesis by salivary gland lymphoid cells in Sjögren's syndrome. Journal of Clinical Investigation, 49, 49.

TAlal, N. \& Bunim, J.J. (1964) The development of malignant lymphomas in the course of Sjögren's syndrome. American Journal of Medicine, 36, 529.

Talal, N., SoKoloff, L. \& BaRTh, W.F. (1947) Extra salivary lymphoid abnormalities in Sjögren's syndrome (Reticulum cell sarcoma, pseudo-lymphoma, macroglobulinaemia). American Journal of Medicine, 43, 50.

ThORPE, P. (1969) Polymalgic rheumatica-A not so benign syndrome. Medical Journal of Australia, 2, 678.

ZAWADZKI, Z.A. \& Ewards, G.A. (1970) Dysimmunoglobulinaemia associated with hepato-biliary disorders. American Journal of Medicine, 58, 196. 